\title{
ANALISIS KEBUTUHAN PENGEMBANGAN SUBJECT SPECIFIC PEDAGOGY ETNOMATEMATIKA UNTUK MENINGKATKAN KEMAMPUAN BERPIKIR KRITIS
}

\author{
Rino Richardo ${ }^{1}$, Adhetia Martyanti ${ }^{2}$, Suhartini $^{3}$ \\ ${ }^{1,2,3}$ Program Studi Pendidikan Matematika Universitas Alma Ata
}

\begin{abstract}
Indonesian law number 14 of 2005 concerning Teachers and Lecturers suggests that pedagogical competence is an ability to manage students' learning process, with one of the indicators is teachers must have an ability to plan a teaching and learning process. The planning includes all units of learning devices called as Subject Specific Pedagogy (SSP). Understanding SSP is a crucial matter to be developed since teachers do not have understanding about it comprehensively and students are less facilitated with critical thinking skills. The objective of the study is describing the needs of teachers and students for the development of Subject Specific Pedagogy (SSP) based on ethnomatematics to improve critical thinking skill. The method used in the study is qualitative with survey approach. This research is conducted at State Junior High School (SMPN) 1 Piyungan Yogyakarta. The research subjects are mathematics teachers and students at the eighth grade by using purposive sampling technique. Data collection techniques are carried out questionnaires through interviews. Data analysis uses descriptive qualitative analysis. Questionnaire data and interviews are analyzed through data reduction, data presentation, and conclusion. The result show that: (1) Teachers do not have comprehensive knowledge related to Subject Specific Pedagogy (SSP) and they still have obstacles in developing it, (2) Teachers do not understand the ethnomatematics concept in mathematics learning, (3) Teachers have never developed worksheets and tasks which facilitate students in critical thinking, and (4) Students are still difficult in solving mathematics problems, especially problems that require critical thinking skill.
\end{abstract}

Keywords: Ethnomatematics, SSP, Critical, Needs, Development.

\section{PENDAHULUAN}

Proses pembelajaran yang berkualitas tentunya berbanding lurus dengan kemampuan seorang guru sebagai ujung tombak dalam kegiatan pembelajaran. Kemampuan tersebut melekat pada salah satu kompetensi guru yaitu kompetensi pedagogik. Kompetensi pedagogik adalah kemampuan mengelola pembelajaran peserta didik, dengan salah satu indikatornya guru harus memiliki kemampuan merencanakan program pembelajaran. Pembelajaran yang bermutu baik, tidak terlepas dari proses perencanaan yang baik pula. Kemampuan perencanaan terkait dengan kemampuan guru dalam menyusun dan mengembangkan perangkat pembelajaran (Nuraini, 2016). Kegiatan ini meliputi persiapan dalam membuat perangkat-perangkat yang biasa disusun sebelum kegiatan pembelajaran meliputi, Rencana Pelaksanaan Pembelajaran (RPP), silabus, Lembar Kerja Siswa (LKS), hingga metode evaluasi yang akan digunakan. Perangkatperangkat tersebut sering disebut dengan Subject Specific Pedagogy (SSP).

Selain itu, hal penting yang diperlukan adalah mendesain perencanaan tersebut, agar berisi desain materi dan proses pembelajaran sehingga materi dapat disampaikan 
dengan baik serta mampu memfasilitasi peserta didik sehingga memiliki kompetensi yang dibutuhkan pada abad 21 ini. Salah satu kemampuan yang dibutuhkan adalah kemampuan berpikir kritis. Menurut Wijaya (2007), berpikir kritis adalah suatu kegiatan atau proses menganalisis, menjelaskan, mengembangkan atau menyeleksi ide, mencakup mengkategorisasikan, membandingkan, melawankan, menguji argumentasi dan asumsi, menyelesaikan dan mengevaluasikesimpulan induksi dan deduksi, menentukan prioritas dan membuat pilihan. Konsep kritis dalam matematika selalu dikaitkan dengan masalah (problem) yang biasanya dikaitkan dengan kehidupan sehari-hari. Karena melalui masalah, siswa diarahkan untuk mampu mengkonstruksi kerangka pengetahuan dan pemahaman terhadap suatu konsep matematika. Selain itu melalui masalah para siswa akan menjadi terampil dalam memproses pengetahuan agar dapat menemukan dan menciptakan sesuatu (Abdullah dan Richardo, 2017). Sementara Indikator yang menunjukkan bahwa masalah mampu mengukur kemampuan tersebut, maka masalah matematika merupakan soal-soal pada tipe $\mathrm{C} 4, \mathrm{C} 5$, dan $\mathrm{C} 6$, yaitu analyze, evaluate, dan create (Anderson dan Krathwohl, 2010).

Jika dikaitkan dengan dengan kurikulum 2013, pembelajaran tidak hanya mampu mengarahkan siswa berpikir kritis (hanya sisi kognitif), tetapi diharapkan memiliki sisi kebermaknaan. Maksudnya adalah materi pembelajaran tidak hanya menyentuh pada pengalaman sehari-hari, melainkan mampu menyentuh sisi budaya atau kearifan local. Maka dalam hal ini dikenal sebuah kajian dalam matematika yaitu etnomatematika. Etnomatematika merupakan ilmu yang digunakan untuk memahami bagaimana matematika diadaptasi dari sebuah budaya (Marsigit, 2016). Melalui konsep ini diharapkan tidak hanya memfasilitasi kemampuan kognitif, melainkan mampu memfasilitasi kemampuan afektif, yaitu rasa cinta peserta didik dengan budaya sebagai wujud nasionalisme (Richardo, 2016).

Berdasarkan pemaparan diatas, Nampak bahwa kemampuan berpikir kritis memiliki peran yang sangat penting untuk membekali peserta didik sebagaimana tujuan dari pendidikan nasional. Sehingga untuk merealisasikannya dibutuhkan sebuah perencanaan pembelajaran dalam bentuk SSP yang valid, praktis, dan efektif. Tetapi sebelum SSP tersebut mampu diterapkan pada satuan pendidikan yang tepat, maka diperlukan analisis pendahuluan dari urgensi pengembangan SSP nya. Sehingga tujuan dari penelitian ini adalah mendeskripsikan kebutuhan guru dan siswa untuk pengembangan Subject Spesific Pedagogy (SSP) berbasis etnomatematika untuk meningkatkan kemampuan berpikir kritis. 


\section{METODE PENELITIAN}

Penelitian ini menggunakan pendekatan kualitatif dengan pendekatan metode survey. Metode survey adalah menggunakan kuesioner sebagai sumber data utama. Dalam penelitian survey responden diminta untuk memberikan jawaban singkat yang sudah tertulis di dalam kuesioner untuk kemudian jawaban dari seluruh responden diolah menggunakan teknik tertentu (Martono, 2010: 19).

Populasi dalam penelitian ini adalah siswa kelas VIII dan Guru Matematika Kelas VIII SMP N 1 Piyungan. Pengambilan sampelnya dilakukan secara purposive sampling. Purposive sampling yaitu teknik pengambilan sampel yang pengambilannya di dasarkan pada tujuan-tujuan tertentu sesuai dengan kepentingan penelitian, biasanya ditentukan berdasarkan kriteria-kriteria tertentu (Sugiyono, 2005: 78). Sehingga diperoleh sampel yang terdiri dari siswa kelas VIII F sebanyak 28 orang dan 3 orang guru matematika kelas VIII .

Instrumen yang digunakan untuk mengumpulkan data adalah sebagai berikut. 1) Pedoman wawancara terhadap guru untuk memperoleh informasi tentang pengembangan Subject Specific Pedagogy (SSP) berbasis etnomatematika, 2) angket analisis kebutuhan guru untuk memperoleh informasi berkitan dengan Silabus, Rencana Pelaksanaan Pembelajaran (RPP), Lembar Kegiatan Siswa (LKS), dan soal yang dikembangkan dengan mengukur kemampuan berpikir kritis siswa yang dibuat oleh guru matematika, 3) Angket kebutuhan siswa. Analisis data menggunakan analisis kualitatif deskriptif. Data angket dan wawancara dianalisis melalui reduksi data, penyajian data, dan penarikan kesimpulan.

\section{HASIL DAN PEMBAHASAN}

Berdasarkan penelitian yang telah dilakukan, diperoleh data yang dapat diklasifikasikan sebagai berikut.

A. Pengembangan SSP Etnomatematika untuk Meningkatkan Kemampuan Berpikir Kritis Siswa

Subject Spesific Pedagogy(SSP) merupakan perangkat pembelajaran yang dikemas secara komprehensif, utuh dan sistematis untuk materi tertentu (khusus). Dalam penelitian ini, SSP yang dimaksudkan memiliki komponen-komponen antara lain RPP, LKS, dan instrumen penilaian keterampilan berpikir kritis untuk pembelajaran matematika berbasis etnomatematika. Dengan demikian, pada aspek pengembangan SSP etnomatematika untuk meningkatkan kemampuan berpikir kritis siswa, guru diharapkan memiliki pengetahuan tentang RPP, LKS, dan instumen 
penilaianketerampilan berpikir kritis untuk pembelajaran matematika berbasis etnomatematika, serta telah mengembangkan SSP yang dimaksud.

Terkait aspek pengetahuan guru tentang SSP, diperoleh gambaran bahwa seluruh guru telah memiliki pengetahuan tentang SSP. Akan tetapi, pengetahuan tersebut terbatas pada pengetahuan umum tentang unsur-unsur pembentuk komponen SSP. Guru belum memiliki pengetahuan yang komprehensif tentang SSP etnomatematika untuk meningkatkan kemampuan berpikir kritis.

Hasil penelitian juga memberikan gambaran bahwa guru belum mengembangkan SSP secara optimal. Dari penelitian diperoleh bahwa seluruh guru telah mengembangkan RPP dengan cara menyusunnya sendiri, dan $67 \%$ guru telah mengembangkan LKS dan soalnya sendiri. Akan tetapi apabila dianalisis lebih lanjut, diperoleh informasi bahwa dari RPP, LKS dan soal yang dikembangkan oleh guru, belum ada yang berbasis etnomatematika untuk guna meningkatkan kemampuan berpikir kritis siswa. Hal ini terlihat pada bagian pengembangan materi ajar dan LKS yang digunakan dalam pembelajaran. Hasil angket menunjukkan bahwa seluruh guru belum memasukkan unsur etnomatematika dalam materi ajar maupun LKS yang dikembangkan. Hal ini juga diperkuat dengan hasil analisis data dari angket yang diberikan kepada siswa. Dari angket tersebut diperoleh hasil bahwa $100 \%$ siswa menyatakan bahwa dalam pembelajaran guru belum mengaitkan materi yang disampaikan dengan konteks budaya sekitar. Padahal, dengan mengaitkan materi matematika dengan konteks budaya sangat dimungkinkan siswa akan lebih mudah memahami materi karena materi tersebut terkait langsung dengan aktivitas siswa sehari-hari dalam bermasyarakat (Wahyuni, Tias, \& Sani, 2013).

Selain itu dengan menggunakan konteks budaya, guru dapat mengemas soalsoal yang diberikan menjadi lebih bervariasi dan menantang kemampuan berpikir siswa. Sebab ketika siswa menyelesaikan soal matematika berbasis budaya tersebut, siswa akan dituntut untuk menggunakan ketrampilannya seperti menghubungkan (relate), menginterpretasikan (interprete), menerapkan (apply) dan mengintegrasikan (integrate) pengetahuan yang telah dipelajarinya (Widana, dkk, 2017).Ketrampilan ketrampilan yang digunakan dalam menyelesaikan soal tersebut memiliki relevansi dengan indikator - indikator berpikir kritis meliputi interpretasi, analisis, evaluasi, dan keputusan. Dengan kata lain melalui soal berbasis etnomatematika diharapkan guru dapat memfasilitasi siswa untuk berpikir kritis. Akan tetapi, hasil analisis data menunjukkan bahwa seluruh guru yang diobservasi belum mengembangkan soal yang memfasilitasi kemampuan berpikir kritis siswa. Oleh sebab itu diperlukan 
adanya pengembangan soal yang memfasilitasi siswa untuk kemampuan berpikir kritis.

B. Kemampuan Berpikir Kritis Siswa

Gambaran tentang kemampuan berpikir kritis siswa diperoleh dengan memberikan tes kepada siswa. Tes terdiri atas 3 soal essai dimana masing-masing soal dikemas dengan konteks budaya yang terdapat disekitar siswa. ketiga soal yang diberikan merupakan soal yang menuntut siswa untuk berpikir kritis dalam penyelesaiannya, sehingga soal-soal tersebut didesain dengan tipe C4 dan C6.sebagaimana yang diungkapkan oleh Lewy, Zulkardi dan Aisyah (2009) bahwa materi, dalam hal ini termasuk soal yang diberikan, yang mampu mendorong siswa untuk berpikir kritis haruslah bertipe setidaknya C4 (analyze) dan jika mungkin samapai C6 (create).

Berdasarkan hasil analisis data melalui pemberian tes diperoleh informasi yang ditampilkan pada Tabel 1.

\section{Tabel 1. Rekapitulasi Jawaban Siswa}

\begin{tabular}{ccc}
\hline \multirow{2}{*}{ Nomor Soal } & \multicolumn{2}{c}{ Persentase Jawaban Siswa } \\
\cline { 2 - 3 } & Benar & Salah \\
\hline 1 & 53.57 & 46.43 \\
\hline 2 & 53.57 & 46.43 \\
\hline 3 & 39.29 & 67.86 \\
\hline Rata-Rata & 48.81 & 51.19 \\
\hline
\end{tabular}

Infromasi yang terdapat pada Tabel 1 memberikan gambaran bahwa lebih dari $50 \%$ siswa masih memberikan jawaban yang keliru. Hal ini mengindikasikan bahwa siswa masih mengalami kesulitan dalam menyelesaikan soal yang diberikan, dalam hal ini soal yang menuntut siswa untuk berpikir kritis.

Berdasarkan hasil analisis data kemampuan siswa berpikir kritis menunjukkan bahwa diperlukan upaya-upaya yang lebih dalam proses pembelajaran agar siswa memiliki kemampuan berpikir kritis. Salah satunya dengan melaksanakan pembelajaran berbasis etnomatematika. Melalui pembelajaran berbasis etnomatematika, konsep-konsep matematika yang abstrak disampaikan dengan konteks budaya yang dikemas dalam bentuk permasalahan (Martyanti \& Suhartini, 2018). Dalam proses penyelesaian masalah inilah kemampuan berpikir kritis siswa dapat dilatih dan dikembangkan.

Selanjutnya, agar guru dapat melaksanakan pembelajaran berbasis etnomatematika yang efektif untuk meningkatkan kemampuan berpikir kritis maka diperlukan perencanaan. Kegiatan perencanaan ini dapat dilakukan dengan mengembangkan SSP meliputi RPP, LKS dan Instrumen berbasis etnomatematika untuk meningkatkan kemampuan berpikir kritis siswa. Dengan adanya SSP ini 
diharapkan proses pembelajaran yang dilaksanakan guru menjadi lebih terarah sehingga dapat mencapai tujuan yang diinginkan yaitu meningkatkan kemampuan berpikir kritis siswa.

\section{SIMPULAN DAN SARAN}

Berdasarkan hasil analisis data dan pembahasan di atas dapat disimpulkan sebagai berikut. Pertama, guru telah memiliki pengetahuan tentang SSP akan tetapi masih sangat terbatas dan menemui kendala dalam pengembangannya. Kedua, guru belum memahami konsep etnomatematika. Ketiga, guru belum pernah mengembangkan LKS dan soal yang memfasilitasi siswa untuk berpikir kritis. Keempat, siswa masih mengalami kesulitan dalam menyelesaikan soal yang menuntut kemampuan berpikir kritis.

Berdasarkan kesimpulan di atas, maka dapat diberikan saran sebagai berikut. Pertama, perlu dikembangkan SSP yang bisa dijadikan panduan bagi guru dalam melaksanakan pembelajaran, salah satunya SSP berbasis etnomatematika. Kedua, guru dapat melaksanakan pembelajaran berbasis etnomatematika sebagai upaya untuk meningkatkan kemampuan berpikir kritis siswa. Ketiga, perlunya pengembangan LKS dan soal matematika berbasis etnomatematika untuk memfasilitasi siswa berpikir kritis.

\section{DAFTAR PUSTAKA}

Abdullah, A.A. \& Richardo, R. (2017). Menumbuhkan Kemampuan Berpikir Kritis Siswa Dalam Memilih Makanan Sehat Dengan Pembelajaran Literasi Matematika Berbasis Konteks. Jurnal Gantang, 2(2), 89-98.

Lewy, Zulkardi, \& Aisyah, N. (2009). Pengembangan Soal untuk Mengukur Kemampuan Berpikir Tigkat Tinggi Pokok Bahasan Barisan dan Deret Bilangan di Kelas IX Akselerasi SMP Xaverius Maria Palembang. Jurnal Pendidikan Matematika. $3(2), 14-29$.

Martyanti, A. \& Suhartini. (2018). Etnomatematika: Menumbuhkan Kemampuan Berpikir Kritis Melalui Budaya Dan Matematika. Indomath: Indomanesian Mathematics Education, 1(1), 35-41.

Marsigit. (2016). Prosiding Seminar Nasional Pengembangan PembelajaranMatematika Berbasis Etnomatematika. Sumatera Barat: FKIP STKIP SUMBAR

Martono, N. (2010). Metode Penelitian Kuantitatif. Jakarta: PT. Raya Grafindo Persada.

Nuraini, M. T. \& E. T. M. (2016). Analisis Permasalahan Guru Terkait Perangkat Pembelajaran Berbasis Model Pembelajaran Biologi Di SMA. Jurnal Pendidikan, 1(10), 2066-2070.

Richardo, R. (2016). Peran Ethnomatematika Dalam Penerapan PembelajaranMatematika Pada Kurikulum 2013. Literasi, 7(2), 118-125. 
Wahyuni, A., Tias, Ayu Aji W., \& Sani, B. (2013). Prosiding seminar nasional Peran Etnomatematika dalam Membangun Karakter Bangsa. Yogyakarta: FMIPA UNY

Sugiyono. (2005). Metode Penelitian Kuantitatif Kualitatif. Bandung: Alfabeta.

Widana, I.W., dkk. (2017). Modul Penyusunan Soal Higher Order thinking Skill (HOTS). Jakarta: Direktorat Pembinaan SMA, Direktorat Jendral Pendidikan dasar dan Menengah, Departemen Pendidikan Dan Kebudayaan

Wijaya, C. (2007). Pendidikan Remedial. Bandung: Rosdakarya. 